\title{
Risco cardiovascular na adolescência
}

Recentemente, os jornais noticiaram um importante diagnóstico de saúde: "quase metade da população brasileira está acima do peso". A notícia foi baseada nos dados do VIGITEL, pesquisa realizada por telefone, e mostra que entre 2006 e 2011 o percentual de obesos subiu de $11,4 \%$ para $15,8 \%$, e aponta ainda que o problema do excesso de peso começa cedo. Entre os 18 e 24 anos, $29,4 \%$ dos homens e $25,4 \%$ das mulheres já estão acima do peso ideal.

A resistência insulínica e mesmo o diabetes tipo II têm sido relatados em menores de 18 anos. A hipertensão arterial primária torna-se cada vez mais frequente, refletindo o aumento do excesso de peso. Outras consequências da obesidade em adolescentes também são observadas, tais como: distúrbios respiratórios como asma e apneia do sono; acometimento articular, principalmente joelhos e quadril; e até transtornos mentais. Sabemos ainda que a inserção desses jovens no mercado de trabalho é mais difícil.

O Ministério da Saúde tem investido em promoção de hábitos saudáveis visando à prevenção de doenças crônicas e melhoria da qualidade de vida do brasileiro. A redução do consumo de sal e o bem-sucedido programa antitabagista são alguns exemplos dessas iniciativas. Um dos objetivos do Plano de Ações Estratégicas para o Enfrentamento das Doenças Crônicas não Transmissíveis, lançado em 2011, é parar o aumento da proporção de adultos acima do peso ideal. Uma das estratégias utilizadas é o Programa Academia da Saúde, que visa a aumentar a prática da atividade física da população. A Pesquisa Nacional de Saúde do Escolar (PeNSE) e o Programa Saúde na Escola (PSE) são iniciativas voltadas especificamente para as populações mais jovens.

O Departamento de Ciência e Tecnologia do Ministério da Saúde definiu como uma das prioridades da pesquisa em saúde conhecer o perfil de risco cardiovascular e metabólico dos adolescentes brasileiros. Por meio de edital lançado em 2008, em parceria com a FINEP e o CNPq, foi aprovado financiamento para o Estudo de Risco Cardiovascular em Adolescentes (ERICA). Essa pesquisa vem sendo planejada há três anos e o seu estudo piloto está em curso em cinco cidades. O piloto avaliará os protocolos de aplicação dos instrumentos e da logística dessa complexa pesquisa. O objetivo principal do ERICA é estimar a prevalência de obesidade, resistência insulínica, diabetes tipo II, hipertensão arterial, dislipidemia e tabagismo, em uma amostra de 75 mil adolescentes de 12 a 17 anos, que frequenta escolas públicas e privadas de cidades brasileiras com mais de 100 mil habitantes.

Espera-se que os resultados do ERICA possam desenhar o mosaico da distribuição de fatores de risco cardiovascular, e de alguns fatores a eles relacionados, permitindo comparações regionais e o levantamento de hipóteses sobre determinantes do estado de saúde atual dos adolescentes. Embora o conhecimento existente já permita o delineamento de estratégias de prevenção e promoção de saúde, como as que têm sido conduzidas pelo Ministério da Saúde, a obtenção de informações mais detalhadas de curvas de peso, estatura, circunferência da cintura e pressão arterial poderá subsidiar políticas de saúde e servir como referência para futuras pesquisas na área de doenças não transmissíveis.

Katia Vergetti Bloch

Instituto de Estudos em Saúde Coletiva, Universidade Federal do

Rio de Janeiro, Rio de Janeiro, Brasil.

kbloch@globo.com

\section{Moyses Szklo}

Instituto de Estudos em Saúde Coletiva, Universidade Federal do Rio de Janeiro, Rio de Janeiro, Brasil.

mszklo@jhsph.edu

Maria Cristina Kuschnir

Núcleo de Estudos da Saúde do Adolescente, Universidade do

Estado do Rio de Janeiro, Rio de Janeiro, Brasil.

Instituto Nacional de Cardiologia, Rio de Janeiro, Brasil.

cristina.kuschnir@gmail.com 


\section{Cardiovascular risk in adolescence}

Brazilian newspapers recently published an important health diagnosis: "Nearly half of the Brazilian population is overweight." The news story was based on data from VIGITEL, the Telephone Survey for Surveillance of Chronic Non-Communicable Diseases and showed that from 2006 to 2011 the obesity rate increased from $11.4 \%$ to $15.8 \%$, also highlighting that the excess weight problem begins at early ages. Among individuals 18 to 24 years of age, $29.4 \%$ of men and $25.4 \%$ of women are already above their ideal weight.

Insulin resistance and even type II diabetes have been reported in individuals younger than 18 years. Primary arterial hypertension is becoming increasingly frequent, reflecting the increase in excess weight. Other consequences of obesity in adolescents have also been observed: respiratory disorders like asthma and sleep apnea; joint involvement, especially knees and hips; and even mental disorders. Overweight and obese young individuals are also known to experience greater difficulty in entering the labor market.

The Ministry of Health has invested in promoting healthy habits aimed at the prevention of chronic diseases and improving quality of life for Brazilians. The reduction in salt intake and the successful anti-tobacco program are two examples of such initiatives. One of the objectives of the Strategic Action Plan to Fight Chronic Non-Communicable Diseases, launched in 2011, is to halt the increase in the proportion of overweight adults. One of the Plan's strategies is the Health Gym Program, aimed at increasing physical exercise in the population. The National School Health Survey (PeNSE) and School Health Program (PSE) are initiatives that focus specifically on the younger population groups.

The Department of Science and Technology in the Brazilian Ministry of Health has defined the cardiovascular and metabolic risk profile of Brazilian adolescents as a key health research priority. Through a call for projects issued in 2008 in partnership with the FINEP and CNPq research agencies, funding was approved for the Study on Cardiovascular Risk in Adolescents (ERICA, in Portuguese). The research has been planned for three years, and its pilot study is under way in five cities. The pilot study will evaluate the protocols for application of the instruments and logistics in this complex research. The principal objective of ERICA is to estimate the prevalence of obesity, insulin resistance, type II diabetes, arterial hypertension, dyslipidemia, and smoking in a sample of 75,000 adolescents from 12 to 17 years of age enrolled in public and private schools in Brazilian cities with more than 100,000 inhabitants.

The results of ERICA should depict the mosaic in the distribution of cardiovascular risk factors and some related factors, allowing regional comparisons and raising hypotheses on the determinants of the adolescents' current health status. Although existing knowledge already allows designing prevention and health promotion strategies such as those conducted by the Ministry of Health, obtaining more detailed information on weight, height, waist circumference, and blood pressure curves can back health policies and serve as a reference for future studies in the area of non-communicable diseases.

\author{
Katia Vergetti Bloch \\ Instituto de Estudos em Saúde Coletiva, Universidade Federal do \\ Rio de Janeiro, Rio de Janeiro, Brasil. \\ kbloch@globo.com
}

\author{
Moyses Szklo \\ Instituto de Estudos em Saúde Coletiva, Universidade Federal do \\ Rio de Janeiro, Rio de Janeiro, Brasil. \\ mszklo@jhsph.edu
}

Maria Cristina Kuschnir

Núcleo de Estudos da Saúde do Adolescente, Universidade do

Estado do Rio de Janeiro, Rio de Janeiro, Brasil.

Instituto Nacional de Cardiologia, Rio de Janeiro, Brasil.

cristina.kuschnir@gmail.com 